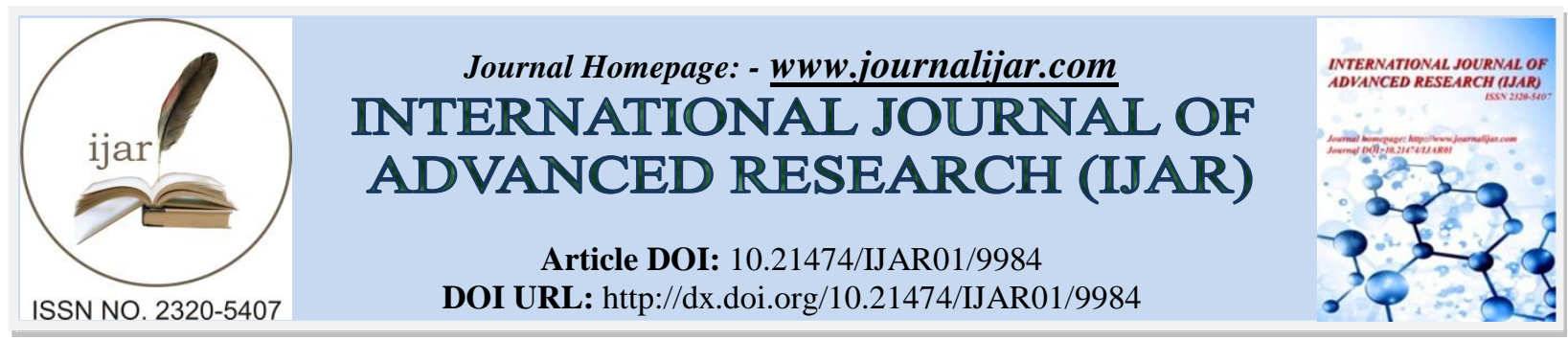

RESEARCH ARTICLE

\title{
RAINFALL VARIABILITY IN NIGER: CASE OF GOUDOUMARIA.
}

\section{Ado Salifou Hadiza ${ }^{1,2}$, Abarchi Idrissa ${ }^{3}$, Oumani Amadou Abdoulaye ${ }^{4}$ and Yamba Boubacar ${ }^{1}$.}

1. Département de Géographie, Faculté des lettres et Sciences Humaines, Université Abdou Moumouni de Niamey, BP: 10960, Niamey, Niger.

2. Département de Sociologie, Anthropologie, Economie et Communication, Institut Supérieur en Environnement et Ecologie, Université de Diffa, BP: 78, Diffa, Niger.

3. Département de Sciences du Sol et de Télédétection, Université Dan Dicko Dankoulodo de Maradi, BP: 465 Maradi, Niger.

4. Département de Génie Rural, Eaux et Foret, Université Dan Dicko Dankoulodo de Maradi, BP: 465 Maradi, Niger.

\section{Manuscript Info}

\section{Manuscript History}

Received: 05 September 2019

Final Accepted: 07 October 2019

Published: November 2019

Key words:-

Goudoumaria, spatio-temporal variability, rainfall, ecological zone, south east of Niger.

\section{Abstract}

Goudoumaria is located in the extreme south east of Niger and is part of ecological zones with strong climatic constraints especially rainfall. It is characterized by a strong spatio-temporal variability. The objective of this study is to identify the irregular nature of its distribution overtime that influences agropastoral activities. The results reveal rainfall interannual variability, its concentrations from June to September, a late start and early end and a downward trend. These results lead to a good understanding of rainfall evolution in the study area.

Copy Right, IJAR, 2019,. All rights reserved.

\section{Introduction:-}

In the Sahel, rainfall is the most important climatic variable in the dynamics of agropastoral and pastoral ecosystems. Therefore, rainfall can be considered as the most appropriate indicator for the analyzing climate change as it can be used lonely to characterize the climate (Ozer et al., 2005 cited by Maman, 2013). Thus, its insufficiency and its bad distribution over time is a limiting factor for vegetation and crops (Caseneuve and valentin, 1989).

Niger Republic covers an area of $1.267 .000 \mathrm{~km}^{2}$ and is located between $12^{\circ}$ and $23^{\circ}$ north latitude, $00^{\circ} 16^{\prime}$ and $16^{\circ}$ east longitude. It is characterized by all types of arid and semi arid ecosystems. The climate is sudano-sahelian and sahelian in the south band and Saharan in the northern part of the country. The rainfall is characterized by a very large temporal and spatial variability and a tendency to aridification (PPCR - Niger, 2010). Thus the objective of the present study is to identify the irregular nature of rainfall distribution overtime that influences agropastoral activities.

\section{Material and Methods:-}

\section{Study site}

The study was conducted in the department of Goudoumaria located between $13^{\circ} 38^{\prime}$ and $14^{\circ} 09^{\prime}$ north latitude and $10^{\circ} 65^{\prime}$ and $11^{\circ} 26^{\prime}$ east longitude (Figure 1). The climate of the study area is sahelian. It is characterized by a long dry season and a short wet season. Rainfall is low and unevenly distributed over time and space.

Corresponding Author:-Ado Salifou Hadiza.

Address:-Département de Géographie, Faculté des lettres et Sciences Humaines, Université Abdou Moumouni de Niamey, BP: 10960, Niamey, Niger. 


\section{Data analysis}

The procedure consisted of a treatment and analysis of long climatic series, their criticism as well as tests on the stationarity and nonstationarity of time series and statistical calculation such as trends and variability.

Trends were highlighted from the lamb standardization index (1982). This index characterized the trend of variables such as annual cumulative rainfall, the number of rainy days, the date of beginning and the date of ending rains, the length of season, the maximum and minimum temperature (Lona, 2010).

The index I is equal to (Xi - Xmoy) / $\delta$

Where,

$\mathrm{Xi}=$ observation for the year $\mathrm{i}$.

X mean: average of the 1961-1990 series which is the normal accepted by the scientific community for all studies on climatic changes in the Sahel.

$\delta=$ standard deviation of the 1961-1990 series.

\section{Break time series test of pettit}

Climatic data were subjected to the pettit rupture test. At the end of the climate series test, the results are presented in graphical form in order to detect the different breaks.

\section{Rainfall data used}

The daily rainfall data in complete series recorded at the Goudoumaria rainfall station from 1960 to 2016, those of Mainé soroa from 1960 to 2010 and some results from investigation on rainfall data of the rainfall post of Gouré (Lona, 2014) were used.

\section{Key climatic factors of the season}

The analysis of the rainfall requires having indicators that informs about the different events taking place in its unfolding (starting date of the rainy season, ending date of the rainy season, lenght of the rainy season, rainfall total amont, and reference period). These events are Key features of the success or failure of agricultural season (Sarr, 2006) and also pastoral activities.

\section{Results and Discussion:-}

The analysis of rainfall data from 1960 to 2016 from the Goudoumaria substation made it possible to characterized the rainfall dynamics of the area. It is marked by high variability (Figure 2). The evolution of rainfall in this zone shows a succession of abnormally wet years (1961; 1966; 1974; 1975, 1994, 2010 and 2016); excessively wet which date back to 1960 and deficient years $(1973 ; 1983 ; 1984 ; 1990 ; 2004$ and 2014). However, the discrimination of these years conceals the strong variability mentioned above. The rainy season tends to start late and ends earlier. This situation has increased significantly in recent years (Figure 3). Rainfalls are generally concentrated from June to September and with low cumulative rainfall in March-April (Figure 4). These are linked to the descent of an intertropical polar air that causes "mango rains" (Desconnet 1994 cited by Harouna, 2005). The high cumulative rainfall of a year do not in themselves condition the success of pastoral activities, a concomitance of the start date of the season and the first sowing is more than necessary. Also, the adequacy between dry sequences and the evolution of plants, in short, the unfolding of agricultural activities with the end date of the rainy season. For example, the 2016 campaign, during which a lot of accumulation of rainfall were recorded, but yields were very low. These sequences are obstacle to the agricultural system in the Sahel (Seyni et al., 2012). It is therefore important to study these parameters for a better control of the practice of agricultural activities. The exceptionally wet year is the predrought period of 1960; 1964 in particular.

The lowest accumulation are observed in deficit or dry years that are $(1973 ; 1983 ; 2009 ; 1984 ; 1990 ; 2004$; 2014) for which the accumulations are lower than $200 \mathrm{~mm}$. The rains and their duration (number of rainy days) decreases but in a less sensitive manner (Figure 5). The average of the first 30 years of 322,73 mm has fallen to the level of the last 20 years with $294,53 \mathrm{~mm}$ because of the regression of rainfall heights observed in certain years. But despite the slight return of rainfall conditions observed across the totals, the trends remains downwards (Figure 2). In addition to this, Goudoumaria station is the most deficient compared to the neighboring stations (Table 1). A clear break is observed (Figure 6) from 1967 due to the sharp decrease in precipitation recorded at all stations in the Sahel, but also those of West Africa (Paturel et al., 2004; CEDEAO-CSAO/OCDE, 2006 ; Michel and Dieudonné, 
2009 ; Ozer, 2005). It is noted that in Goudoumaria, the 1960 was the rainiest in the 1961-2016 series, which is marked by high inter-decadal variability (Figure 7).

\section{Conclusion:-}

The evolution of rainfall is marked by a succession of wet and deficit years. Globally, three periods emerges from this evolution, that of before the drought of 70s, when the precipitations were abundant; the advent of major droughts with the mediocrity of some annual rainfall and the current periods market by a return of rains. During these last two periods, there is a strong variability in rainfall which introduces uncertainty in the courses of agropastoral activities.

However, the study of overall characteristics of rainfall does not allow seeing at best its influence on agropastoral activities. There is need for further research on aspects that more impacts using suitable models.

\section{Acknowledgements:-}

The authors are grateful to the LaSyRe-Sahel Project for sponsoring the first part of field activities.

Table 1:- Comparision of the average rainfall of the Goudoumaria area and those of neighboring stations

\begin{tabular}{|l|l|l|l|}
\hline Station & $\begin{array}{l}\text { Mean } \\
1961-1990\end{array}$ & $\begin{array}{c}\text { Mean } \\
1991-2010\end{array}$ & Difference \\
\hline Goudoumaria & 314,7 & 278 & $-36,7$ \\
\hline Gouré & 286,3 & 313,6 & 27,3 \\
\hline Mainé soroa & 343 & 329,1 & $-13,9$ \\
\hline
\end{tabular}

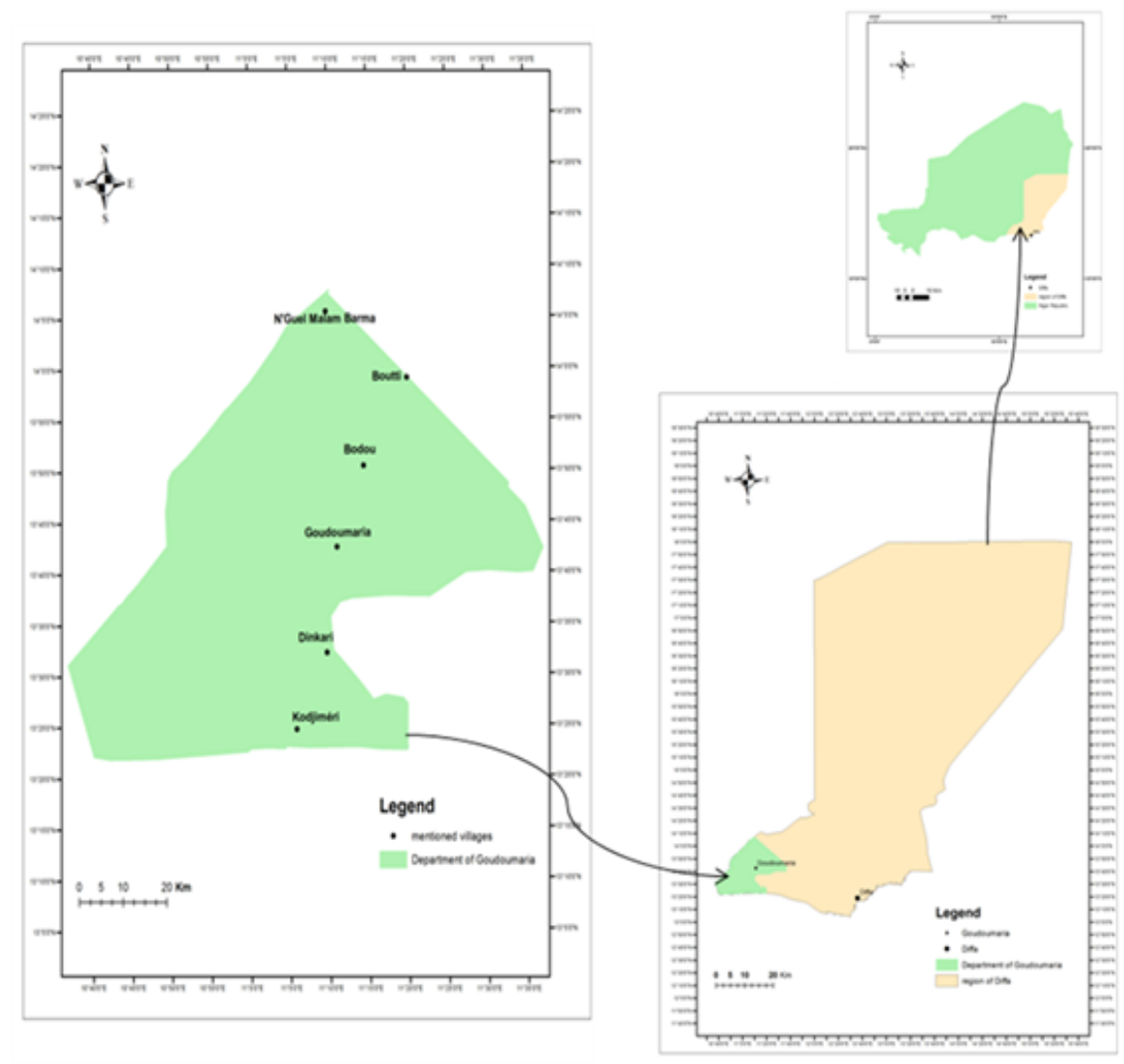

Figure 1:- Map of the study area 


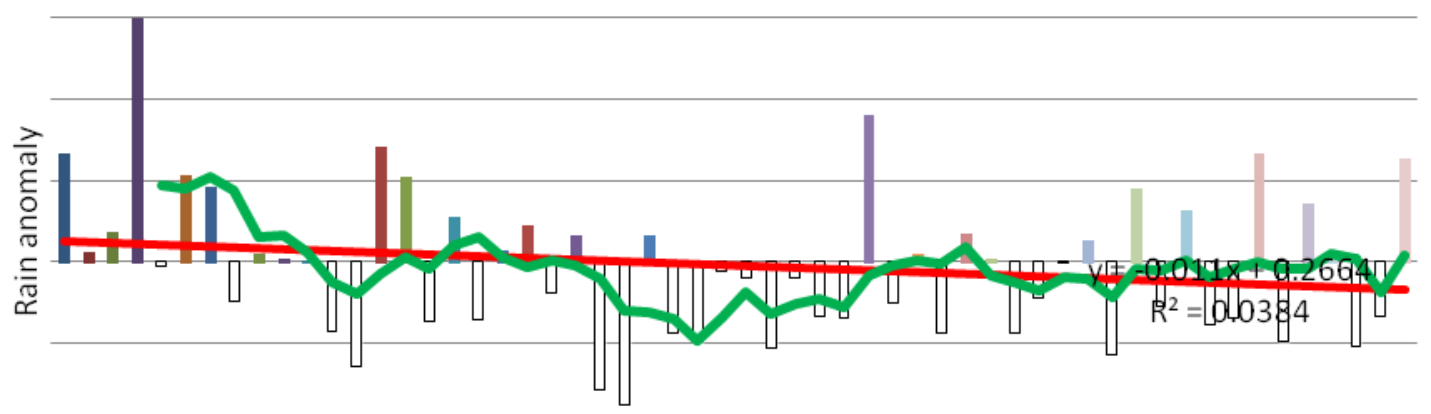

Standardized anomaly of the annual average

Linear trend of the annual average rainfall

Five year trend of the annual average rainfall

Figure 2:- Rain anomally recorded at the Goudoumaria station
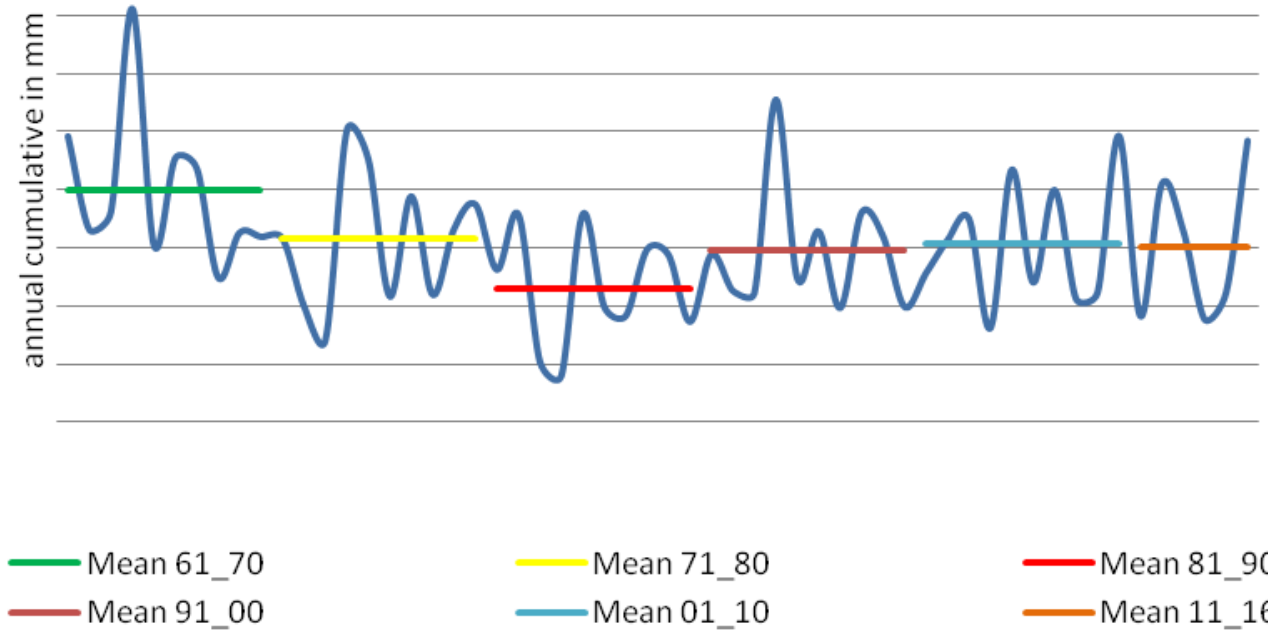

Mean 71_80
Mean 01_10

-Mean 81_90

Mean 11_16

Figure 3:- Evolution of the dates of the begining and the end of rain in the area of Goudoumaria 


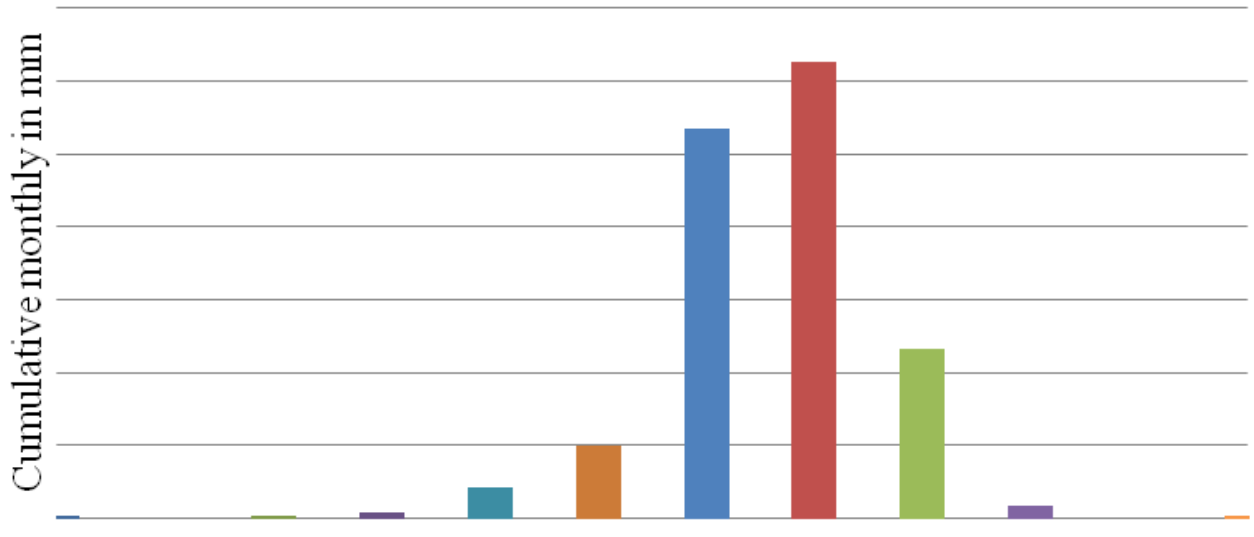

Month

Figure 4:- Average monthly rainfall of the Goudoumaria area

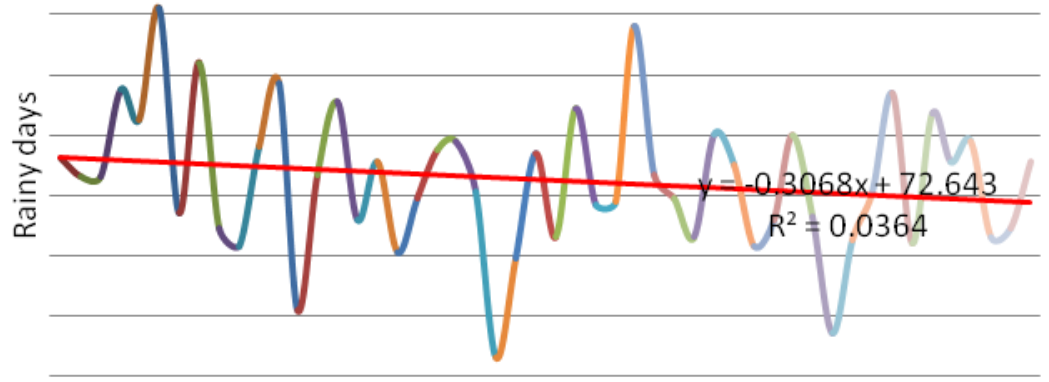

Number of rainy days _ _ linaer trend of number of rainy days

Figure 5:- Evolution of the number of rainy days in the area of Goudoumaria 


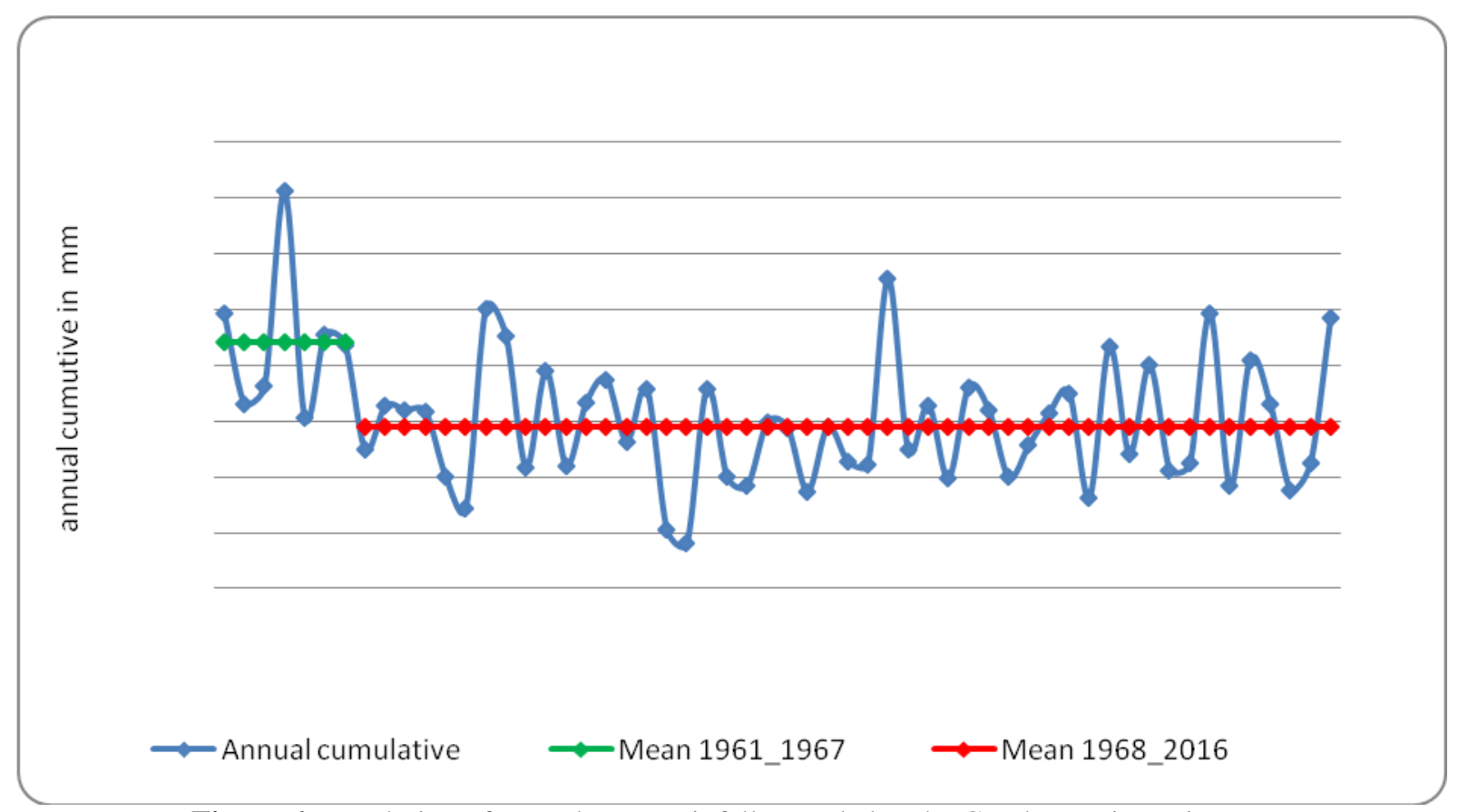

Figure 6:- Evolution of annual mean rainfall recorded at the Goudoumaria station

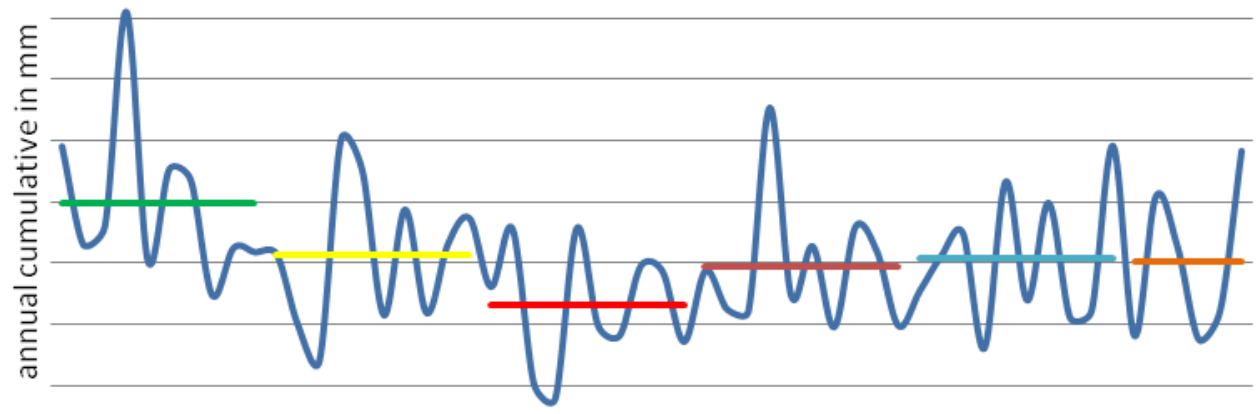

\section{References:-}
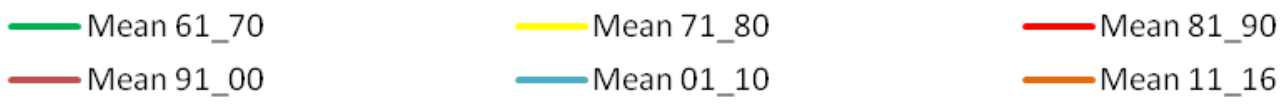

Figure 7:- Evolution of the ten year rainfall recorded at the Goudoumaria station

1. Casenave, A., et Valentin, C., (1989): Les états de surface de la zone sahélienne, ORSTOM, Bondy, 220 pages.

2. CEDEAO-CSAO/OCDEC., (2006): La zone écologique fragile des pays du Sahel, in atlas de l'intégration régionale en Afrique de l'ouest, série environnement, 12 pages.

3. Harouna, H. H., (2005): Dynamique locale de l'ensablement et évaluation et l'efficacitéanti-érosive de quelques techniques de fixation des dunes dans le département de Maïné-Soroa (Sud-Est du Niger), Mémoire de DEA, Département de Géographie, Université Abdou Moumouni de Niamey, 68 pages.

4. Lona, I., (2014): Etude des données climatiques de la commune de Gouré ; 20 pages. 
5. Maman, I., (2013): Etude intégrée de la résilience des systèmes sociaux de la limite nord des cultures pluviales dans le département de Goudoumaria face au changement climatique, thèse de doctorat, Université Abdou Moumouni de Niamey, 285 pages.

6. Michel, A.B. et Goudou, D.G., (2009): Inventaire des connaissances sur la résilience climatique au Niger, programme pilote résilience climatique, Rapport final.

7. Ozer, A., (2005): Analyse climatique de la région de Gouré, Niger oriental : récentes modifications et impacts environnementaux. In Revue Européenne de Géographie mai 2005 ; n 308, 24 pages.

8. Paturel, J.E., Boubacar, I., L'Aour, A., (2004): Evolution de la pluviométrie annuelle en Afrique de l'ouest et centrale au XXème siècle ; Sud Sciences \& Technologies $N^{\circ} 13$ décembre $2014 ; 7$ pages.

9. Programme Pilote pour la Resilience Climatique - Niger., (2010): Aide mémoire mission conjointe, Niamey, 86 pages.

10. Seyni, S., Bertrand, M., Amadou, T. G., Frederic, H., Ndiaga, C., (2012): Analyses multi-échelles des pauses pluviométriques au Niger et au Sénégal, Sécheresse vol. 23, No. 8 1, janvier-février-mars 2012, 11 pages. 